\title{
Role of Catalase as Semen Additive in Cryopreservation of Cattle Bull Semen
}

\author{
Padamveer Singh $^{1}$, Sanjay Agarwal ${ }^{1}{ }^{*}$, Harjyote Singh ${ }^{1}$, Ajay Kumar Sharma ${ }^{4}$, \\ Pawan Kumar Verma ${ }^{2}$ and Sharad Kumar ${ }^{3}$
}

${ }^{1}$ Divison of Veterinary Gynaecology \& Obstetrics, ${ }^{2}$ Division of Veterinary Pharmacology and Toxicology, ${ }^{3}$ Division of Teaching Veterinary Clinical Complex, F.V.Sc. \& A.H., S.K.U.A.S.T.J., R. S. Pura-181102, Jammu, India

${ }^{4}$ Frozen Semen Laboratory, U.T. of Jammu \& Kashmir, Hukkal, Jammu, India

*Corresponding author

\section{A B S T R A C T}

The present study was done at the Frozen Semen Laboratory, U.T. of Jammu \& Kashmir, Hukkal, Jammu and Division of V.G.O., F.V.Sc \& A.H., SKUAST- J, R.S.Pura, during the period between December 2017 and May 2018. This investigation was carried out with the

\section{Keywords}

Semen, Cattle bull, Catalase, Oxidative stress

Article Info

Accepted:

22 July 2020

Available Online:

10 August 2020 objective to study the effect of antioxidant semen additive catalase on cryopreservation of semen. Semen samples $(n=10)$ from mature cattle bull stationed at Frozen semen laboratory, U.T. of Jammu \& Kashmir, Hukkal, Jammu, were used to evaluate the effect of catalase additive at post-dilution and at post thaw stage. The semen sample was extended with Tris-Egg-Yolk-Citric-acid-Fructose-Glycerol (TEYCAFG) extender and were split into two groups: Group 1: TEYCAFG without any additive/ control and group 2: TEYCAFG + Catalase (100 IU/ml). Progressive motility, live spermatozoa, acrosomal integrity, sperm abnormality, hypo-osmotic swelling test (HOST) was evaluated at both post-dilution and post-thaw stage. Whereas, oxidative stress tests viz. malondialdehyde (MDA), catalase (CAT) and superoxide dismutase (SOD) were evaluated at only postthawed stage. Group 2 i.e. catalase group, showed significant $(\mathrm{p}<0.05)$ increased progressive motility, live spermatozoa, acrosomal integrity and HOST positive spermatozoa, while significant $(\mathrm{p}<0.05)$ decreased sperm abnormalities in post-thawed semen. In oxidative stress evaluation the MDA level was significantly $(\mathrm{p}<0.05)$ decreased, whereas, CAT and SOD levels significantly $(\mathrm{p}<0.05)$ increased in group 2 in comparison to control group. It was concluded that addition of catalase $(100 \mathrm{IU} / \mathrm{ml})$ as semen additive improves semen quality and minimize oxidative stress to the spermatozoa during cryopreservation of semen.

\section{Introduction}

Artificial insemination (AI) is the most important single technique devised for the genetic improvement of animals. This improvement has been exponential in dairy cattle, in which use of frozen semen is most common. A prerequisite for the best use of this genetic material is to obtain acceptable fertility after AI apart from achieving a high 
milk production (Karunakaran et al., 2012). But the freezing and thawing process leads to the generation of reactive oxygen species (ROS) that impairs post-thaw motility, viability, intracellular enzyme activity, fertility and sperm functions (Aitken et al., 1998; Zhao and Buhr, 1995; White, 1993).

The damage during cryopreservation is mainly due to cold shock, ice crystal formation, oxidative stress, osmotic changes and lipid-protein reorganization within the cell membranes (Bailey et al., 2000; Watson, 1995). The sperm cells contain high contents of polyunsaturated fatty acids (PUFA) which makes the membranes more susceptible to peroxidative damage. The protective antioxidant systems in spermatozoa are primarily of cytoplasmic origin which is generally lost during terminal stages of differentiation, thus lack antioxidants that counteract the damaging effects of ROS (Bucak et al., 2010). Spermatozoa and seminal plasma possess an antioxidant system comprising of taurine, reduced glutathione (GSH), glutathione peroxidase (GSH-Px), catalase (CAT), and superoxide dismutase (SOD) to prevent oxidative damage. However, this antioxidant capacity in sperm cells, due to small cytoplasmic component containing antioxidants to scavenge oxidants, is limited. Thus, mammalian spermatozoa are unable to prevent formation of lipid peroxidation (LPO) during freeze -thawing process (Bucak et al., 2010; Aurich et al., 1997; Storey, 1997).

In recent years, the addition of antioxidants such as reduced glutathione (GSH), ascorbic acid, taurine, cysteine to bovine semen has shown to protect effects of ROS and improve post-thaw sperm motility, viability and fertility.

Catalase is frequently used additives to sperm suspensions in order to improve sperm characteristics. Catalase is a common enzyme found in all living organisms exposed to oxygen. Catalase specifically removes hydrogen peroxide by converting this oxidant to water and oxygen (Baker et al., 1996). It is an enzymatic antioxidant exists in peroxisomes, which can convert hydrogen peroxide metabolism to water and oxygen and neutralize the toxic effects of free radicals (Teke, 2014). It is the first intracellular defense system against ROS and free radicals (Caballero, 2007). Catalase also improves oocyte penetration of bull spermatozoa (Rossi et al., 2001).

To best of our knowledge, the studies are deficient in investigation of the roles of addition of catalase in semen of cross-bred bull of Jammu and Kashmir region. In continuation to our previous reported findings in cryopreservation of cross-bred cattle bull semen (Singh et al., 2020) the present study was designed with the objective to evaluate the oxidative stress to the spermatozoa during cryopreservation of semen and the effects of catalase as semen additive.

\section{Materials and Methods}

The present study was undertaken at the Division of V.G.O., F.V.Sc \& A.H., SKUAST- J, R.S. Pura and Frozen semen laboratory, U.T. of Jammu \& Kashmir, Hukkal, Jammu during the period between December 2017 and May 2018. Semen samples $(n=10)$ were collected randomly from mature cattle bull stationed at Frozen semen laboratory, U.T. of Jammu \& Kashmir, Hukkal, Jammu, India $\left(32.73^{\circ} \mathrm{N}, 74.87^{\circ} \mathrm{E}\right.$, altitude $300 \mathrm{~m}$ ). Semen was collected twice a week from each bull by artificial vagina method. The semen ejaculates were initially evaluated for volume, mass activity, spermatozoa concentration and progressive motility. The ejaculates qualifying the minimum initial standards were further 
processed. After initial assessment of semen, the selected samples were extended with prewarmed $\left(37^{\circ} \mathrm{C}\right)$ Tris egg yolk citric acid fructose glycerol (TEYCAFG) extender so that each $\mathrm{ml}$ of extended semen contained at least $40 \times 10^{6}$ spermatozoa (Anel et al., 2003). After extension, the semen samples were divided into two parts. The first part was considered as group 1: TEYCAFG without any additive/ control and group 2: TEYCAFG + Catalase (100 IU/ml). The $\mathrm{pH}$ was adjusted within the range 7.2 to 7.4 . The semen samples were filled in $0.5 \mathrm{ml}$ capacity, polyvinyl straw (IMV, France). Equilibration was done in the cold handling unit maintained at $4^{\circ} \mathrm{C}$ for 4 hours. Freezing of the straws was done by programmable biofreezer (Digit Cool-530, IMV Technologies, France) with rate freezing from $4^{\circ} \mathrm{C}$ to $-10^{\circ} \mathrm{C}$ @ $5^{\circ} \mathrm{C}$, $10^{\circ} \mathrm{C}$ to $-100^{\circ} \mathrm{C} @ 40^{\circ} \mathrm{C},-100^{\circ} \mathrm{C}$ to $-140^{\circ} \mathrm{C} @$ $20^{\circ} \mathrm{C}$, after attainment of $-140^{\circ} \mathrm{C}$ temperature the straws were removed from the racks shifted to the pre-cooled goblets and plunged into liquid nitrogen and finally stored in liquid nitrogen tank where they were stored for definite period of time for future evaluation.

Total ejaculates $(n=10)$ were evaluated at two stages of the semen processing viz. postdilution and post thaw stage, for per cent progressive motility, live spermatozoa, acrosomal integrity, sperm abnormalities and hypo-osmotic swelling test. Whereas, only at post-thaw stage for oxidative stress test viz. MDA, SOD and Catalase. Thawing of frozen semen was done at $37^{\circ} \mathrm{C}$ for 30 seconds.

Volume was measured by graduated collecting tube, mass activity was graded as described by Tomar et al., (1966). The concentration of the spermatozoa (millions/ml) was determined by Accucell photometer (IMV Technologies, France). Progressive motility, live spermatozoa and acrosome integrity were assessed as per Salisbury et al., (1978); HOST test was performed as described by Jeyendran et al., (1984); sperm abnormalities were assessed by Eosin-nigrosin stain with slight modification as described by Kumar (1993). Oxidative stress test viz. Malondialdehyde (MDA) was determined as described by Shafiq-urRehman (1984); Catalase as per Aebi (1983) and Superoxide dismutase (SOD) as described by Marklund and Marklund (1974). The results were analysed statistically using Analysis of Variance (ANOVA) (Snedecor and Cochran, 1989).

\section{Results and Discussion}

In the present investigation EY-tris (egg yolktris-citric acid-fructose-glycerol) was used as control dilutor, EY-tris plus Catalase (100 $\mathrm{IU} / \mathrm{ml}$ ) were used as experimental groups.

\section{Progressive motility}

The per cent progressive motility (Mean \pm SE) post-dilution and post-thawing in control group were $67.0 \pm 1.52$ and $48.0 \pm 2.49$; whereas in catalase added group were $68.0 \pm$ 1.33 and $58.0 \pm 1.33$, respectively (Table 1 ). Perusal of the table 1 it was observed that the progressive motility (\%) differed non significantly between post-diluted control and Catalase added group, whereas, in post-thaw a significant $(\mathrm{p}<0.05)$ difference in progressive motility was observed between control and catalase group.

In the present study in control group the per cent progressive motility of diluted semen (Table 1) was $67.0 \pm 1.52$ which was in agreement with the finding of Pathak et al., (1990) who reported per cent progressive motility as $65.30 \pm 1.20$ per cent in diluted semen of cattle bull. The per cent progressive motility of post thaw semen is reported as higher as 80.74 (Kishore, 2009), $61.7 \pm 2.6$ (Pawshe et al., 2016), $55.5 \pm 2.5$ (Uysal et al., 2007), $55.34 \pm 1.02$ (Ulfina and Raina, 2003), 
$36.88 \pm 1.53$ (Hu et al., 2010) and as low as $14.7 \pm 1.4$ (Li et al., 2016).

In the present study per cent post thaw motility in control group (Table 1) was $48.0 \pm$ 2.49 which was less than reported by Kishore (2009), Pawshe et al., (2016), Uysal et al., (2007) and Ulfina and Raina (2003), while it was higher than reported by $\mathrm{Hu}$ et al., (2010) and $\mathrm{Li}$ et al., (2016). The main reason for the decrease in the per cent post thaw progressive motility might be due to cryopreservation damage, ROS production and damage caused due to formation of ice crystal formation in mitochondria and Axomemes during cryopreservation that impairs sperm motility.

In the present study in catalase added group the values of per cent progressive motility of diluted semen (Table 1) was $68.0 \pm 1.33$, The per cent progressive motility in diluted semen was observed by various scientist as $80 \pm$ $7.58,80 \pm 1.54,80 \pm 2.16$ in three different bulls with $100 \mathrm{IU}$ of catalase and $85 \pm 1.63$, $85 \pm 2.86,80 \pm 4.71$ in three different cattle with $200 \mathrm{IU}$ of catalase (Bansal and Cheema, 2016), $64.0 \pm 18.2$ in cattle bull with $200 \mathrm{IU}$ of catalase (Fernandez-Santos et al., 2009).

In the present study the per cent post thaw progressive motility in catalase added group was recorded as $58.0 \pm 1.33$. It has been previously reported as $65 \pm 0.94,50 \pm 4.02$, $57.5 \pm 0.62$ in post thaw semen of three different bulls with $100 \mathrm{IU}$ of catalase and 70 $\pm 4.71,57.5 \pm 6.24,63.75 \pm 2.33$ in post thaw semen of three different bulls with $200 \mathrm{IU}$ of catalase (Bansal and Cheema, 2016), $46.70 \pm$ 2.89 in post thaw semen of cattle bull with 100 IU of catalase and 43.30 in post thaw semen of cattle bull with 200 IU of catalase (Asadpour et al., 2011), $41.0 \pm 11.4$ in post thaw semen of cattle bull with 200 IU of catalase (Fernandez-Santos et al., 2009).

In present study the value of per cent progressive motility in diluted semen of catalase added group (Table 1) was $68.0 \pm$ 1.33 , which was in agreement with the Fernandez-Santos et al., (2009), whereas lesser than the finding of Bansal and Cheema (2016).

The value of per cent progressive motility in post thaw semen of catalase added group (Table 1) in present study was $58.0 \pm 1.33$ which was in agreement with Bansal and Cheema (2016) with 200 IU of catalase, while it was higher than finding of Asadpour et al., (2011), Fernandez-Santos et al., (2009) and lesser than finding of Bansal and Cheema (2016) with 100 IU of catalase.

\section{Live spermatozoa}

The per cent live spermatozoa (Mean \pm SE) post-dilution and post-thawing in control group were $74.4 \pm 1.82$ and $50.8 \pm 1.17$; whereas in catalase group were $77.7 \pm 1.25$ and $60.8 \pm 1.14$, respectively (Table 1). Perusal of the table 1 it was observed that the live spermatozoa (\%) differed non significantly between post-diluted control and catalase group, whereas, in post-thaw a significant $(\mathrm{p}<0.05)$ difference in live spermatozoa was observed between control and catalase group.

In the present study in the control group values of per cent live spermatozoa in diluted semen (Table 1) was $74.4 \pm 1.82$. in the previous study the per cent live spermatozoa in diluted semen was observed as 74.28 (Keshava, 1996), $73.0 \pm 1.3$ (Abdel-khalek et $a l ., 2008$ ) and $72.44 \pm 0.51$ (Ulfina and Raina, 2003). In the present study the values of per cent live spermatozoa in diluted semen of control group (Table 1) was $74.4 \pm 1.82$, which was in agreement with the findings of Keshava (1996) and Abdel-khalek et al., (2008). The per cent spermatozoa in post thaw semen was reported as $60.76 \pm 0.68$, $57.64 \pm 0.78$ (Bhalde et al., 1991), $56.24 \pm$ 0.01 (Rao et al., 2017) and 66-73 per cent 
(Abdel-khalek et al., 2008). In the present study the values of per cent live spermatozoa of post thaw semen of control group (Table 1) was $50.8 \pm 1.17$ which was less than reported by Bhalde et al., (1991), Rao et al., (2017) and Abdel-khalek et al., (2008). Decreasing proportion of live spermatozoa in post thaw semen may be due to cryo damage caused to formation of ice crystals in extra and intracellular environment, increasing solute concentration (Mazur, 1984) and sperm susceptibility for freezing and thawing temperature, ROS production and lipid peroxidation (Bucak et al., 2008)

In the present study in catalase added group the value of per cent live spermatozoa of diluted semen was $77.7 \pm 1.25$. The per cent live spermatozoa in diluted semen was observed by various scientist as $97.29 \pm 4.85$, $88.42 \pm 1.73,91.02 \pm 3.29$ in three different bulls with $100 \mathrm{IU}$ of catalase and $92.45 \pm$ $5.91,86.3 \pm 3.44,93.2 \pm 1.79$ in three different bulls with 200 IU of catalase (Bansal and Cheema, 2016). In the present study in catalase added group the value of per cent live spermatozoa of post thaw semen was $60.8 \pm$ 1.14. In the previous study the per cent live spermatozoa in post thaw semen was observed as $59 \pm 2.82,64.39 \pm 3.11,61.69 \pm$ 8.16 in post thaw semen of three different bulls with 100 IU of catalase and $59 \pm 2.82$, $64.39 \pm 3.11,61.69 \pm 8.16$ in post thaw semen of three different bulls with $200 \mathrm{IU}$ of catalase (Bansal and Cheema, 2016), $59.0 \pm 23.9$ in post thaw semen of cattle bull with $200 \mathrm{IU}$ of catalase (Fernandez-Santos et al., 2009), $51.70 \pm 2.90$ in post thaw semen of cattle bull with $100 \mathrm{IU}$ of catalase and $200 \mathrm{IU}$ of catalase (Asadpour et al., 2011).

In our study the value of per cent live spermatozoa in diluted semen of catalase added group (Table 1) was $77.7 \pm 1.25$, which was lesser than the finding of Bansal and Cheema (2016).
The value of per cent live spermatozoa in post thaw semen of catalase added group (Table 1) in present study was $60.8 \pm 1.14$ which was in agreement with finding of Fernandez-Santos et al., (2009) and Bansal and Cheema (2016), whereas lower values were observed in the finding of Asadpour et al., (2011).

\section{Acrosomal integrity}

The per cent acrosomal integrity (Mean \pm SE) post-dilution and post-thawing in control group were $79.7 \pm 1.52$ and $53.9 \pm 0.94$; whereas in catalase group were $81.4 \pm 1.32$ and $66.3 \pm 1.31$, respectively (Table 1). Perusal of the table 1 it was observed that the acrosomal integrity (\%) differed non significantly between post-diluted control and catalase group, whereas, in post-thaw a significant $(\mathrm{p}<0.05)$ difference in acrosomal integrity was observed between control and catalase group.

The evaluation of acrosomal integrity is important for determination of semen quality as enzyme necessary for fertilization present in the acrosomal cap. The per cent acrosomal integrity in diluted semen was reported as $85.77 \pm 0.01$ in crossbred bull (Rao et al., 2017 ) and $80.17 \pm 3.26$ in buffalo bull (Lone et al., 2017). In the present study the values of per cent acrosomal integrity of diluted semen of control group (Table 1) was $79.7 \pm 1.52$, which was in agreement with the finding of Lone et al., (2017), it was less than the finding of Rao et al., (2017).

The per cent acrosomal integrity in post thaw semen was reported as $56.24 \pm 0.01$ in crossbred bull (Rao et al., 2017), $36.25 \pm 0.91$ in murrah buffalo bull (Sandeep et al., 2015), $31.5 \pm 1.3$ in crossbred bull (Paudel et al., 2010). In the present study the values of per cent acrosomal integrity of post thaw semen of control group (Table 1) was $53.9 \pm 0.94$ which was in agreement with the finding of 
Rao et al., (2017), however it was higher than the finding of Sandeep et al., (2015) and Paudel et al., (2010).

Studies have shown, Cryopreservation induces various degrees of acrosomal damage that may be primary, secondary or teriary damage. There is reduction of $20-30 \%$ in acrosomal intactness during time of post thaw evaluation of spermatozoa. The decrease in acrosomal integrity at various stages may be due to loss of component of plasma membrane and loss of plasmalemma over entire acrosome during freeze- thawing.

In the present study in catalase added group the values of per cent acrosomal integrity of diluted semen (Table 1) was $81.4 \pm 1.32$, whereas, the values of per cent acrosomal integrity of post thaw semen (Table 1) was $66.3 \pm 1.31$. In previous study the value per cent acrosomal integrity in post thaw semen was recorded as $35.9 \pm 1.4$ (Paudel et al., 2010) which was lower than the present study finding i.e. $66.3 \pm 1.31$.

\section{Sperm abnormalities}

The per cent sperm abnormalities (Mean \pm SE) post-dilution and post-thawing in control group were $7.2 \pm 0.63$ and $16.8 \pm 0.61$; whereas in catalase group were $7.1 \pm 0.69$ and $12.7 \pm 0.42$, respectively (Table 1 ). Perusal of the table 1 it was observed that the sperm abnormalities (\%) differed non significantly between post-diluted control and catalase group, whereas, in post-thaw a significant $(p<0.05)$ difference in sperm abnormalities was observed between control and catalase group.

The per cent sperm abnormalities in diluted semen was observed as $4.91 \pm 0.14$ in bhadawari bull (Mittal et al., 2014) $7.28 \pm$ 0.02 in crossbred bull (Rao et al., 2017) and $9.14 \pm 0.09$ in cattle bull (Gupta et al., 1990). In the present study the values of per cent sperm abnormalities in diluted semen of control group (Table 1) was $7.2 \pm 0.63$, which was in agreement with the finding of Rao et al., (2017), however it was higher than as reported by Mittal et al., (2014) while it was lower than as reported by Gupta et al., (1990).

The per cent sperm abnormalities in post thaw semen is reported by various scientists as 7.75 \pm 0.17 in Bhadawari bull (Mittal et al., 2014), $14.93 \pm 1.07$ in cattle bull (Sariozkan et al., 2009a), $15.0 \pm 1.1$ in cattle bull (Sariozkan et al., 2009b), in the range of $15.66 \pm 0.39$ to $16.75 \pm 0.37$ in Jersey bulls (Rao et al., 1999), $17.63 \pm 1.99$ in cattle bull (Gupta et al., 1990) and $18.36 \pm 0.04$ in crossbred bull (Rao et al., 2017).

In the present study per cent post thaw sperm abnormalities in control group (Table 1) was $16.8 \pm 0.61$ which was in agreement with the finding of Rao et al., (1999) while it was higher than as reported by Mittal et al., (2014), Sariozkan et al., (2009a) and Sariozkan et al., (2009b) whereas lower than the finding of Gupta et al., (1990) and Rao et al., (2017).

In the present study in catalase added group the value of per cent sperm abnormalities of diluted semen (Table 1) was $7.1 \pm 0.69$. In previous work the value of per cent of sperm abnormalities in diluted and post thaw semen observed by Fernandez-Santos et al., (2009) as $10.0 \pm 2.0$ and $14.0 \pm 6.6$, respectively, which is higher than the value in our present study in diluted semen and post thaw semen of catalase added group (Table 1) i.e. $7.1 \pm$ $0.6912 .7 \pm 0.42$, respectively. 
Table.1 The effect of catalase on different physio-morphological characteristics at post-dilution and post-thaw semen of cross-bred bulls

\begin{tabular}{|l|l|l|c|}
\hline Parameter (\%) & Stage & Control & Catalase $\mathbf{( 1 0 0 ~ I U / m I ) ~}$ \\
\hline Progressive motility & Post-dilution & $67.0 \pm 1.52^{\mathrm{a}}$ & $68.0 \pm 1.33^{\mathrm{a}}$ \\
\cline { 2 - 4 } & Post-thaw & $48.0 \pm 2.49^{\mathrm{a}}$ & $58.0 \pm 1.33^{\mathrm{b}}$ \\
\hline \multirow{2}{*}{ Live spermatozoa } & Post-dilution & $74.4 \pm 1.82^{\mathrm{a}}$ & $77.7 \pm 1.25^{\mathrm{a}}$ \\
\hline \multirow{2}{*}{ Acrosomal integrity } & Post-thaw & $50.8 \pm 1.17^{\mathrm{a}}$ & $60.8 \pm 1.14^{\mathrm{b}}$ \\
\hline \multirow{2}{*}{ Sperm abnormalities } & Post-dilution & $79.7 \pm 1.52^{\mathrm{a}}$ & $81.4 \pm 1.32^{\mathrm{a}}$ \\
\cline { 2 - 4 } & Post-thaw & $53.9 \pm 0.94^{\mathrm{a}}$ & $66.3 \pm 1.31^{\mathrm{b}}$ \\
\hline \multirow{2}{*}{ HOST } & Post-dilution & $7.2 \pm 0.63^{\mathrm{a}}$ & $7.1 \pm 0.69^{\mathrm{a}}$ \\
\cline { 2 - 4 } & Post-thaw & $16.8 \pm 0.61^{\mathrm{a}}$ & $12.7 \pm 0.42^{\mathrm{b}}$ \\
\hline & Post-dilution & $71.0 \pm 1.10^{\mathrm{a}}$ & $73.1 \pm 1.30^{\mathrm{a}}$ \\
\cline { 2 - 4 } & Post-thaw & $45.4 \pm 0.93^{\mathrm{a}}$ & $53.8 \pm 0.87^{\mathrm{b}}$ \\
\hline
\end{tabular}

Values are given as mean \pm SE of 10 animals unless and otherwise stated

Values bearing different superscripts in a row differ significantly $(\mathrm{p}<0.05)$

Table.2 The effect of Catalase on malondialdehyde (MDA), catalase (CAT) and superoxide dismutase (SOD) activity in post-thawed semen of cross-bred bulls

\begin{tabular}{|c|c|c|}
\hline Oxidative stress test & Control & Catalase $(\mathbf{1 0 0} \mathbf{~ I U} / \mathbf{m l})$ \\
\hline MDA (nmol/10 $\mathbf{1 0}^{\mathbf{8}}$ Spermatozoa) & $3.49 \pm 0.19^{\mathrm{a}}$ & $1.62 \pm 0.04^{\mathrm{b}}$ \\
\hline CAT $\left(\boldsymbol{\mu m o l} / \mathbf{1 0}^{\mathbf{8}}\right.$ Spermatozoa) & $1.18 \pm 0.36^{\mathrm{a}}$ & $1.46 \pm 0.40^{\mathrm{b}}$ \\
\hline SOD $\left(\mathbf{U} / \mathbf{1 0}^{\mathbf{8}}\right.$ Spermatozoa) & $0.95 \pm 0.06^{\mathrm{a}}$ & $1.42 \pm 0.05^{\mathrm{b}}$ \\
\hline
\end{tabular}

Values are given as mean \pm SE of 10 animals unless and otherwise stated

Values bearing different superscripts in a row differ significantly $(\mathrm{p}<0.05)$

\section{Hypo-osmotic swelling test (HOST)}

The hypo-osmotic swelling test positive spermatozoa per cent (Mean \pm SE) postdilution and post-thawing in control group were $71.0 \pm 1.10$ and $45.4 \pm 0.93$; whereas in catalase group were $73.1 \pm 1.30$ and $53.8 \pm$ 0.87 , respectively (Table 1 ). Perusal of the table 1 it was observed that the hypo-osmotic swelling test positive spermatozoa (\%) differed non significantly between postdiluted control and catalase group, whereas, in post-thaw a significant $(\mathrm{p}<0.05)$ difference in hypo-osmotic swelling test positive spermatozoa was observed between control and catalase group.

The per cent hypo-osmotic swelling test (HOST) positive spermatozoa in diluted semen is reported as $72.54 \pm 0.01$ in crossbred bull (Rao et al., 2017), $70.91 \pm 5.92$ in buffalo bull (Lone et al., 2017) and $62.05 \pm 0.80$ in pure Jersey bulls and $62.11 \pm 0.89$ in crossbred Jersey bulls (Kumar et al., 2018).

In the present study the per cent hypo-osmotic swelling test (HOST) positive spermatozoa of diluted semen in control group (Table 1) was $71.0 \pm 1.10$ which was in agreement with the findings of Rao et al., (2017) and Lone et al., (2017), however lower values of per cent hypo-osmotic swelling test (HOST) of diluted semen was observed by Kumar et al., (2018).

The per cent hypo-osmotic swelling test (HOST) positive in post thaw semen is reported as $51.30 \pm 4.43$ in buffalo bull (Lone et al., 2017), $49.97 \pm 3.62$ in sahiwal cattle 
bull (Sohail et al., 2015), $47.27 \pm 1.05$ in pure Jersey bulls and $45.94 \pm 1.33$ crossbred Jersey bulls (Kumar et al., 2018), $43.70 \pm 1.96$ in cattle bull (Sariozkan et al., 2009a), $39.6 \pm$ 1.3 in crossbred bulls (Paudel et al., 2010), $38.73 \pm 0.01$ in crossbred bull (Rao et al., 2017) and 36.52 in cattle bull (Taraphdar, 1999). In the present study the values of per cent hypo-osmotic swelling test (HOST) of post thaw semen of control group (Table 1) was $45.4 \pm 0.93$, which was agreement with the finding of Kumar et al., (2018) and Sariozkan et al., (2009a), while lower values were observed by Paudel et al., (2010), Rao et al., (2017) and Taraphdar (1999) whereas higher finding was observed by Lone et al., (2017) and Sohail et al., (2015). The structural changes produced in the post thaw sperm cells membrane are primarily linked to altered abilities for energy sourcing which later on influence both cellular metabolism and other sperm functions (Dziekonska et al., 2009; Gillan et al., 2004).

In the present study in catalase added group the values of per cent HOST positive of diluted semen has been reported as $73.1 \pm$ 1.30. The value per cent of hypo-osmotic swelling test (HOST) in diluted semen was reported as $93.63 \pm 2.93,55.78 \pm 10.76,74.7$ \pm 4.85 in three different bulls with 100 IU of catalase and $99 \pm 13.81,61 \pm 5.65,68 \pm 4.24$ in three different cattle with 200 IU of catalase (Bansal and Cheema, 2016) and the value per cent of hypo-osmotic swelling test (HOST) in post thaw semen reported as 41.6 \pm 1.3 in cross bred bull with $200 \mathrm{IU}$ of catalase (Paudel et al., 2010), $52.34 \pm 1.77$, $36 \pm 5.65,44.17 \pm 6.51$ in three different bulls with $100 \mathrm{IU}$ of catalase \& $54.39 \pm 1.31,36 \pm$ $1.69,45.19 \pm 3.21$ in three different cattle with $200 \mathrm{IU}$ of catalase (Bansal and Cheema, 2016). In the present study the per cent hypoosmotic swelling test (HOST) of diluted semen with catalase added group (Table 1) was $73.1 \pm 1.30$ which is in agreement with diluted semen with 100 IU of catalase by Bansal and Cheema (2016).

The value for per cent hypo-osmotic swelling test (HOST) of post thaw semen with catalase added group was $53.8 \pm 0.87$ which is in agreement with post thaw semen with $100 \mathrm{IU}$ and $200 \mathrm{IU}$ of catalase by Bansal and Cheema (2016), however lower value was observed by Paudel et al., (2010).

\section{Malondialdehyde (MDA)}

The MDA levels (Mean \pm SE) post-thaw semen samples in control group and catalase group were $3.49 \pm 0.19$ and $1.62 \pm 0.04$, respectively (Table 2). Perusal of the table 2 it was observed that MDA levels in post-thaw semen samples differed significantly $(\mathrm{p}<0.05)$ between control and catalase group.

The MDA level (nmol $\mathrm{H}_{2} \mathrm{O}_{2}$ produced/ $10^{8}$ spermatozoa) of post thaw semen in 712.1 \pm $49.1 \mathrm{nmol}$ MDA level $/ 10^{9}$ spermatozoa in crossbred bull (Paudel et al., 2010), $496.02 \pm$ $39.28 \mathrm{nmol}$ MDA level $/ 10^{9}$ spermatozoa in buffalo bull (Lone et al., 2017). In the present study MDA level (nmol $\mathrm{H}_{2} \mathrm{O}_{2}$ produced/ $10^{8}$ spermatozoa) in post thaw semen of control group (Table 2) was $3.49 \pm$ 0.19 which was lower than the value observed by Paudel et al., (2010) and Lone et al., (2017). The finding of other scientists could not be compared with our finding due to disparity in method of evaluation and units of measurement.

There was an increase in MDA production over a period of 72 hour storage at refrigeration temperature in both cattle and buffalo bull spermatozoa, it indicated that spermatozoa were under increased oxidative stress during storage that resulted in higher LPO (Nair et al., 2006). Since the determination of LPO was based on reaction of thiobarbituric acid (TBA) with the MDA 
produced during the process of oxidative destruction of membranes (Buege and Aust, 1978), it was, therefore, an indirect measure of the peroxidation of polyunsaturated fatty acyl moieties of spermatozoa membranes. The mammalian sperm membrane has high polyunsatured fatty acids (PUFA), it renders the sperm very susceptible to LPO, which occurs as a result of the oxidation of the membrane lipids by partially reduced oxygen molecules, such as superoxide, hydrogen peroxide, and hydroxyl radicals. Jones and Mann (1976) also reported that phospholipids in spermatozoa were the prime targets for peroxidation, of which certain polyunsaturated acyl moieties were particularly vulnerable.

In the present study, the MDA level (nmol $\mathrm{H}_{2} \mathrm{O}_{2}$ produced/ $10^{8}$ spermatozoa) post thaw semen of catalase added group (Table 2) was $1.62 \pm 0.04$. The MDA level (nmol $\mathrm{H}_{2} \mathrm{O}_{2}$ produced/ $10^{8}$ spermatozoa) of post thaw semen was $483.6 \pm 45.0$ (MDA level $\mathrm{nmol} / 10^{9}$ spermatozoa) in $200 \mathrm{IU} / \mathrm{ml}$ of catalase in crossbred bulls (Paudel et al., 2010) and $58.56 \pm 6.63,539.97 \pm 10.78$, $129.26 \pm 40.37$ (nmoles of $\mathrm{MDA} / \mu \mathrm{g}$ protein $/ \mathrm{ml} / 10^{6}$ spermatozoa) in three different bulls with $100 \mathrm{IU}$ of catalase and $277.28 \pm$ $38.58,73.83 \pm 6.85,75.55 \pm 2.77$ (nmoles of $\mathrm{MDA} / \mu \mathrm{g}$ protein $/ \mathrm{ml} / 10^{6}$ spermatozoa) in three different cattle with 200 IU of catalase (Bansal and Cheema, 2016) and $5.32 \pm 1.32$ (nmol/10 ${ }^{9}$ spermatozoa) in cattle bulls with $100 \mathrm{IU}$ of catalase and $4.42 \pm 0.18\left(\mathrm{nmol} / 10^{9}\right.$ spermatozoa) in cattle bulls with 200 IU of catalase (Asadpour et al., 2011).

In present study MDA level of post thaw semen in catalase added group (Table 2) was $1.62 \pm 0.04$ which is lower than the finding of Paudel et al., (2010) and 100 IU of catalase by Bansal and Cheema (2016) whereas higher than the finding of 200 IU of catalase by Bansal and Cheema (2016) and Asadpour et al., (2011), though the finding of other scientists could not be compared with our finding due to disparity in method of evaluation and units of measurement.

\section{Catalase}

The catalase levels (Mean \pm SE) post-thaw semen samples in control group and catalase added group were $1.18 \pm 0.36$ and $1.46 \pm$ 0.40 , respectively (Table 2 ). Perusal of the table 2 it was observed that catalase levels in post-thaw semen samples differed significantly $(p<0.05)$ between control and catalase group.

The catalase activity $\left(\mu \mathrm{mol} \mathrm{H}_{2} \mathrm{O}_{2}\right.$ decomosed/ $\mathrm{min} / 10^{8}$ spermatozoa) in post thaw semen has been reported as $1.16 \pm 0.82(\mathrm{U} / \mathrm{ml})$ in Qinchuan bulls (Zhao et al., 2015), $23.36 \pm$ 0.25 in rainy season, $24.25 \pm 0.30$ winter season and $24.22 \pm 0.56$ in summer season, respectively in buffalo bull (Sharma et al., 2016). In the present study catalase activity ( $\mu$ mol $\mathrm{H}_{2} \mathrm{O}_{2}$ decomosed/ $\mathrm{min} / 10^{8}$ spermatozoa) in post thaw semen of control group (Table 2) was $1.18 \pm 0.31$ which was higher than finding of Zhao et al., (2015) whereas lower than the finding of Sharma et al., (2016). There was reduction in the catalase activity with the level of freezing. CAT activity reduced at post thaw stage when compared to pre freeze stage (Lone et al., 2017). CAT is an enzymatic antioxidant found in all living organisms exposed to oxygen, which decomposes harmful peroxides and converts them into water and oxygen (Chelikani et al., 2004).In the present study, in the Catalase added group the level of Catalase ( $\mu \mathrm{mol} \mathrm{H}_{2} \mathrm{O}_{2}$ decomosed/ $\mathrm{min} / 10^{8}$ spermatozoa) in post thaw semen (Table 2) was $1.46 \pm 0.40$. There was reduction in the catalase activity with the level of freezing. CAT activity reduced at post thaw stage when compared to pre freeze stage (Lone et al., 2017). 


\section{Superoxide dismutase (SOD)}

The SOD levels (Mean \pm SE) post-thaw semen samples in control group and catalase added group were $0.95 \pm 0.06$ and $1.42 \pm$ 0.05 , respectively (Table 2). Perusal of the table 2 it was observed that SOD levels in post-thaw semen samples differed significantly $(\mathrm{p}<0.05)$ between control and catalase group.

The level of Superoxide dismutase (Unit/ $10^{8}$ spermatozoa) in post thaw semen have been reported as $104.02 \pm 26.34$ ( $\mu \mathrm{kat} / \mathrm{g}$ protein) in cattle bull (Sariozkan et al., 2009a), $7.2 \pm 1.8$ (U/g protein) in cattle bull semen (Sariozkan et al., 2009b), $3.50 \pm 0.19$ in cattle and $1.98 \pm$ 0.09 in buffalo bulls (Nair et al., 2006) and $0.16 \pm 0.03$ (units/mg protein) in buffalo bulls (Lone et al., 2017). The level of Superoxide dismutase (Unit/ $10^{8}$ spermatozoa) in present study in post thaw semen of control group (Table 2) was $0.95 \pm 0.06$ which was lower than the finding of Nair et al., (2006), however it was higher than the finding of Lone et al., (2017). Superoxide is a free radical which is converted to oxygen and hydrogen peroxide by the dismutation action of antioxidant enzyme superoxide dismutase (Tariq et al., 2015).

In the present study, the level of Superoxide dismutase (Unit/ $10^{8}$ spermatozoa) in post thaw semen of catalase added group (Table 2) was $1.42 \pm 0.05$. In previous studies the post thaw semen has been reported as $501.74 \pm$ $20.39,307.21 \pm 6.5,504.47 \pm 12.5\left(\mathrm{Unit} / 10^{9}\right.$ spermatozoa) in three different bulls with 100 IU of catalase and $902.4 \pm 9.3,175.39 \pm 2.17$, $638.89 \pm 3.71$ (Unit/10 $10^{9}$ spermatozoa) in three different bulls with $200 \mathrm{IU}$ of catalase (Bansal and Cheema, 2016).

In present study the level of Superoxide dismutase of post thaw semen in catalase added group (Table 1) was $1.42 \pm 0.05$, which is lower than the finding of Bansal and Cheema (2016). Asadpour et al., (2011) stated addition of CAT was ineffective on the post thawing viability of spermatozoa while Roca et al., (2005) reported that the addition of CAT enzyme to semen extender improves post thaw sperm viability and fertility.

In conclusion, the present study with Catalase $(100 \mathrm{IU} / \mathrm{ml})$ as the semen additive may be used for the cryopreservation of the semen. The parameters of semen quality improved in the catalase added cryopreserved semen in comparison of control group. The oxidative stress to the semen is also minimized after addition of the catalase. The in vitro fertility assessed by hypo-osmotic swelling test also indicates for the better quality and fertility in catalase, however, the larger number of the semen samples coupled with field fertility trials should be done in the cattle population for its final validation.

\section{References}

Abdel-Khalek, A.E., Aboul-Ela, S.M.B., Fawzy, A.Q. and Dandooush, E. 2008. Semen quality of holstein and buffalo bulls after filtration using sepahdex column. J. Bio. Sci., 15: 91-97.

Aebi, H. 1983. Catalase. In: Methods in Enzymatic Analysis. Bergmeyer HU (ed). Academic Press, New York. pp 276-286.

Aitken, R.J., Gordon, E., Harkiss, D., Twigg, J.P., Milne, P., Jennings, Z. and Irvine, D.S. 1998. Relative impact of oxidative stress on the functional competence and genomic integrity of human spermatozoa. Bio. Reprod., 59(5): 1037-1046.

Anel, L., DePaz, P., Alvarez, M., Chamorro, C.A., Boixo, J.C., Manso, A., Gonzalez, M., Kaabi, M. and Anel, E. 2003. Field and in vitro assay of three methods for freezing ram semen. 
Theriogenology, 60(7): 1293 -1308.

Asadpour, R., Jafari, R. and Nasrabadi, H.T. 2011. Effect of various levels of catalase antioxidants in semen extenders on lipid peroxidation and semen quality after the freeze-thawing bull semen. Vet. Res. Forum, 2(4): 218-221.

Aurich, J.E., Schonherr, U., Hope, H. and Aurich, C. 1997. Effect of antioxidants on motility and membrane integrity of chilled-stored stallion semen. Theriogenology, 48: 185-192.

Bailey, J.L., Morrie, A. and Cormier, N. 2003. Semen cryopreservation: success and persistent in farm species. Can. J. Anim. Sci., 83: 393-401.

Baker, G.H.W., Brindle, J., Irvine, S.D. and Aitken, R.J. 1996. Protective effect of antioxidants on the impairment of sperm motility by activated polymorphonuclear leukocytes. Fertil. Sertil., 65: 411-419.

Bansal, A.K. and Cheema, R.S. 2016. Effect of catalase on sperm function tests, lipid peroxidation and superoxide dismutase enzyme activity during cryopreservation of buffalo bull semen. Int. Res. J. of Nat. and App. Sci., 3(11): 168-184.

Bhalde, R.M., Hukeni, V.B. and Deopaskas, V.L. 1991. Post thaw keeping quality of frozen bull semen maintained at room/ chilled temperature. Indian $\mathrm{J}$. Anim. Reprod., 12(1): 87-90.

Bucak, M.N., Atessahin, A. and Yuce, A. 2008. Effect of anti-oxidants and oxidative stress parameters on ram semen after the freeze-thawing process. S. Rum. Res., 75(2): 128-134.

Bucak, M.N., Tuncer, P.B., Sarızkan, S., Baspınar, N., Taspınar, M., Coyan, K., Bilgili, A., Akalın, P.P., Buyukleblebici, S., Aydos, S., Ilgaz, S., Sunguroglu, A. and Oztuna, D. 2010. Effects of antioxidants on post- thawed bovine sperm and oxidative stress parameters: antioxidants protect DNA integrity against cryodamage. Cryobiology, 61(3): 248253.

Buege, J.A. and Aust, S.D. 1978. Microsomal lipid peroxidation. Meth. Ezymol.,52: 302-310.

Caballero, B.M.D.2007. Antioxidant nutrients. In: $\mathrm{PhD}$ Thesis. Johns Hopkins University, USA.

Chelikani, P., Fita, I., and Loewen, P.C. 2004. Diversity of structures and properties among catalases. Cel. Mol. L. Sci., 61: 192-208.

Dziekonska, A., Fraser, L. and Strzeżek, J. 2009. Effect of different storage temperatures on the metabolic activity of spermatozoa following liquid storage of boar semen. J. Anim. and Feed Sci., 18: 638-649.

Fernandez-Santos, M.R., Domínguez -Rebolledo, A.E., Esteso, M.C., Garde, J.J., and Martínez-Pastor, F. 2009. Catalase supplementation on thawed bull spermatozoa abolishes the detrimental effect of oxidative stress on motility and DNA integrity. Int. j. of Androl., 32(4): 353-359.

Gillan, L., Maxwell, W.M.C. and Evans, G. 2004. Preservation and evaluation of semen for artificial insemination. Reprod. Fertil. Dev., 16: 447-454.

Gupta, H.P. Saxena, V.B. and Tripathi, S.S. 1990. A rapid method for evaluation of semen quality in bulls. Indian J. Anim. Sci., 60(3): 329-330.

Hu, J.H., Zan, L.S., Zhao, X.L., Li, Q.W., Jiang, Z.L., Li, Y.K. and Li, X. 2010. Effects of trehalose supplementation on semen quality and oxidative stress variables in frozen-thawed bovine semen. J. Aim. Sci., 88(5): 1657-1662.

Jeyendran, R.S., Vander ven, H.H., PerezPelaez, M., Carbo, B.G. and Zanfeld, L.J.D. 1984. Development of an assay 
to assess the functional integrity of the human sperm membrane and its relationship to other semen characteristics. J. Repro. Fertil.,70: 219-228.

Jones, R. and Mann, T. 1977. Toxicity of exogenous fatty acid peroxides towards spermatozoa. J. Repro. Fertil., 50: $255-260$.

Karunakaran, M., Devanathan, T.G., Kulasekar, K., Sridevi, P., Jawahar, T.P., Loganathsamy, K., Dhali, A. and Selvaraju, S. 2012. Effect of heparin binding protein and hydrogen peroxide on lipid peroxidation status of bovine sperm cells. Indian J. Anim. Sci., 82(9): 976-978.

Keshava. P. 1996. Studies on seminal attributes and their association with expected breeding value of dairy bulls. M.Sc. Thesis, NDRI (Deemed University), Karnal, Haryana.

Kishore, A. 2009. Effect of taurine and other additives on preservability of bull semen, PhD thesis, NDRI, Karnal.

Kumar, H., Srivastava, S., Kumar, R., Kumar, R. and Singh, K.D. 2018. Effect of ascorbic acid on storage capacity of Murrah bull epididymal spermatozoa at refrigerator temperature. Int. J. Curr. Microbiol. App. Sci., 7: 4380-4386.

Kumar, M. 1993. Sexual behaviour pattern in sahiwal and murrah bulls. M.Sc. thesis, NDRI, Karnal.

Li, Y., Kalo, D., Zeron, Y. and Roth, Z. 2016. Progressive motility-a potential predictive parameter for semen fertilization capacity in bovines. Zygote, 24(1): 70-82.

Lone, S.A., Prasad, J.K., Ghosh, S.K., Das, G.K., Balamurugan, B. and Verma, M.R. 2017. Study on correlation of sperm quality parameters with antioxidant and oxidant status of buffalo bull semen during various stages of cryopreservation.
Andrologia, 50(4): 1297.

Marklund, S. and Marklund, G. 1974. Involvement of the superoxide anion radical in the autoxidation of pyrogallol and a convenient assay for superoxide dismutase. Eur. J.Biochem., 47(3): 469-474.

Mazur, P. 1984. Freezing of living cells: mechanisms and implications. Am. J. of Physiol., 247: 125-142.

Mittal, P.K., Anand, M., Madan, A.K., Yadav, S. and Kumar, J. 2014. Antioxidative capacity of vitamin E, vitamin $\mathrm{C}$ and their combination in cryopreserved Bhadavari bull semen. Vet. World, 7: 1127-1131.

Nair, S.J., Brar, A.S., Ahuja, C.S., Sangha, S.P.S. and Chaudhary, K.C. 2006. A comparative study on lipid peroxidation, activities of antioxidant enzymes and viability of cattle and buffalo bull spermatozoa during storage at refrigeration temperature. Reprod. Sci., 96(1): 21-29.

Pathak, N., Bunzamin, B.R., Mohan, G. and Sahni, K.L. 1990. Libido in relation to other reproductive trait among the crossbred bulls. Indian J. Anim. Sci., 60(11): 52-54.

Paudel, K.P., Kumar, S., Meur, S.K. and Kumaresan, A. 2010. Ascorbic acid, catalase and chlorpromazine reduce cryopreservation-induced damages to crossbred bull spermatozoa. Reprod. domest. Anim., 45(2): 256-262.

Pawshe, M., Bibin, B., Becha, Unnikrishnan, M.P., Harshan, H.M. and Ghosh, K.N.A. 2016. Bovine semen thawed at $28^{\circ} \mathrm{C}$ or $37^{\circ} \mathrm{c}$ can be used for ai till 90 min post-thaw. Thaw. Bo. sem., 32: 911.

Rao, K.B., Naidu, K.V., Singh, V., Rao, A.S. and Suresh, J. 1999. Studies on semen characteristic of Punganur bulls. Indian Vet. J., 51: 889-900.

Rao, T.K.S., Mohanty, T.K. and Bhakat, M. 
2017. Assessment of antioxidants for preservation of crossbred bull semen in Tris based extender. Indian J. Anim. Res., 51(6): 993-997.

Roca, J., Rodríguez, M.J., Gil, M.A., Carvajal, G., Garcia, E.M., Cuello, C., Vazquez, J.M. and Martinez, E.A. 2005. Survival and in vitro fertility of boar spermatozoa frozen in the presence of superoxide dismutase and/or catalase. J. Androl., 26(1): 1524.

Rossi, T., Mazzilli, F., Delfino, M. and Dondero, F. 2001. Improved human sperm recovery using superoxide dismutase and catalase supplementation in semen cryopreservation procedure. Cell Tissue Bank, 2(1): 9-13.

Salisbury, G.W., Van Denmark, N.L. and Lodge, J.R. 1978. Principles and techniques of freezing spermatozoa. In: Physiology of Reproduction and Artificial Insemination of Cattle. Saliburg, G.A. (edt.), San Francisco: W.H Freeman Co. pp: 454-459.

Sandeep, P.S., Virmani, M. and Malik, R.K. 2015. Effect of vitamin $\mathrm{c}$ on the seminal and biochemical parameters of Murrah buffalo bull semen during different stages of freezing. Haryana Veterinarian, 54(1): 15-18.

Sariozkan, S., Bucak, M.N., Tuncer, P.B., Ulutas, P.A. and Bilgen, A. 2009a. The influence of cysteine and taurine on microscopic-oxidative stress parameters and fertilizing ability of bull semen following cryopreservation. Cryobiology, 58(2): 134-138.

Sariozkan, S., Bucak, M.N., Tuncer, P.B., Ulutas, P.A. and Bilgen, A. 2009b. influence of various antioxidants on microscopic-oxidative stress indicators and fertilizing ability of frozen thawed bull semen. Acta Vet. Brno., 78: 463-
469.

Shafiq-ur-Rehman. 1984. Lead induced regional lipid peroxidation in brain. Toxicology Letters, 21(3): 333-337.

Sharma, L., Pandey, V., Nigam, R., Saxena, A., Swain, D.K. and Yadav. B. 2016. Association of oxidative status and semen characteristics with seminal plasma proteins off buffalo semen. Iranian J. Vet. Res., 17(4): 226-230.

Singh, P., Agarwal, S., Singh, H., Singh, S., Verma, P.K., Butt, M. S. and Sharma, U. 2020. Effects of Ascorbic acid as antioxidant semen additive in cryopreservation of cross-bred cattle bull semen. Int. J. Microbiol. App. Sci., 9(07): 3089-3099.

Snedecor, G. W and Cochran, W. G. 1989. Statistical Methods, $8^{\text {th }}$ edn., Iowa State University Press, USA.

Sohail, M.U., Shahzad, A.H., Iqbal, S., Shabbir, M.S., Iqbal, Z., Abbas, S. and Arshaad, T. 2015. Ascorbic acid inclusion in semen extender improves the post-thawed semen quality of Sahiwal cattle (Bos indicus). Pak. J. Zool., 47(6): 1571-1577.

Storey, B.T. 1997. Biochemistry of the induction and prevention of lipoperoxidative damage in human spermatozoa. Mol. Hum. Reprod., 3: 203-213.

Taraphdar, S. 1999. Studies on initial semen quality, freezability and fertility performance of Murrah buffalo bulls. M.Sc. thesis NDRI (Deemed University), Karnal, Haryana.

Tariq, M., Khan, M.S., Shah, M.G., Nisha, A.R., Umer, M., Hasan, S.M., Rahman, A. and Rabbani, I. 2015. Exogenous antioxidants inclusion during semen cryopreservation of farm animals. J. Chem. and Pharma. Res., 7(3): 2273-2280.

Teke, M. 2014. Development of a new biosensor for determination of catalase 
activity. P. Biochem. Biotechnology, 44: 608-616.

Tomar, N.S., Mishra, B.S. and Johari, C.B. 1966. Seasonal variations in reaction time and semen production, and prediction of some semen attributes on initial motility of spermatozoa in Hariana and Murrah bulls. Indian J. Dairy Sc., 19(1):87-93.

Ulfina, G. and Raina, V.S. 2003. Seminal attributes related to age and scrotal circumference in dairy bulls. Indian J. Dairy Sci., 56(6): 376-379.

Uysal, O., Buck, M.N., Yavas, I. and Varisli. O. 2007. Effect of various antioxidants on the Quality of frozen thawed bull semen. J. Anim. Vet. Ad., 6(12): 1362-1366.

Watson, P.F. 1995. Recent developments and concepts in the cryopreservation of spermatozoa and the assessment of their post-thawing function. Reprod. Fertil. Dev., 7: 871-891.

White, I.G. 1993. Lipids and calcium uptake of sperm in relation to cold shock and preservation: a review. Reprod. Fert. Dev., 5: 639-658.

Zhao, X.L., Li, Y.K., Cao, S.J., Hu, J.H., Wang, W.H., Hao, R.J. and Zan, L.S.2015. Protective effects of Ascorbic acid and Vitamin $E$ on antioxidant enzyme activity of freezethawed semen of Qinchuan bulls. Genet. Mol. Res., 14(1): 2572-2581.

Zhao, Y. and Buhr, M.M. 1995. Cryopreservation extenders affect calcium flux in bovine spermatozoa during a temperature challenge. $\mathrm{J}$. Androl., 16: 278-285.

\section{How to cite this article:}

Padamveer Singh, Sanjay Agarwal, Harjyote Singh, Ajay Kumar Sharma, Pawan Kumar Verma and Sharad Kumar. 2020. Role of Catalase as Semen Additive in Cryopreservation of Cattle Bull Semen. Int.J.Curr.Microbiol.App.Sci. 9(08): 2856-2869.

doi: https://doi.org/10.20546/ijcmas.2020.908.321 